Society for the Anthropology of Work • Policing and Labor

\title{
The "Gypsy" Police: The Social Division of Police Labor in Rome
}

\section{Ana Ivasiuc}

Published on: Dec 01, 2020

DOI: $10.21428 / 1 \mathrm{~d} 6$ be30e.e9e30d29

License: Creative Commons Attribution 4.0 International License (CC-BY 4.0). 
In the name of public order and security, in 2010 the far-right mayor of Rome, Gianni Alemanno, set up a special police unit: the Operative Coordinating Unit for Nomad Settlements. The unit was tasked with policing those to whom Italians erroneously refer as nomads-heterogeneous, but generally precarious Roma groups that started to migrate from Eastern Europe in the 1960s, searching for better lives. At first, they settled informally in the peripheries of Italian cities, forging economic connections with the non-Roma and living off mostly informal livelihoods such as occasional cleaning jobs, begging, dumpster diving, repurposing objects for street markets, and scrap metal trade. In the 1980s, amid the multiculturalist policies advocated for by the Council of Europe, Italian regions passed laws that officially established camps as culturally appropriate housing solution for groups that they lumped together under the same misnomer: thus were born the infamous campi nomadi. Ostensibly intended to "protect nomadic culture," the camps confined and segregated precarious Roma at the margins of Italian society. In Rome, six official and nine "tolerated" camps, ${ }^{1}$ as well as over three hundred informal microsettlements, are now home to a little more than six thousand people, that is, about 0.2 percent of the capital's population. Campi nomadi inevitably figure in political debates as sources of blight and insecurity that mayoral candidates promise to eradicate in every electoral battle.

The responsibilities of the sixty police that make up the unit created by Alemanno concern mainly the eviction of informal settlements of Roma, patrolling the authorized and tolerated camps, and fighting "Gypsy crime" more broadly. With the term nomadi in its original title, the unit had been conceived, in fact, as racial police. However, the name was later changed to the Public and Emergency Security Unit (Gruppo Sicurezza Pubblica Emergenziale; SPE), masking the initial intention of policing a specific racialized and criminalized population. While in Italy the national average of police per capita is 4.5 police per thousand inhabitants, by setting up this particular unit the Roman administration allocated no less than ten police for every thousand inhabitants of the campi nomadi. ${ }^{2}$

Some members of the SPE boast over twenty years of experience with Roma. This was the case for the (now former) commander, Antonio Di Maggio, a very well-known name among Roma, who referred to the SPE as "Di Maggio's men." Dubbed "the sheriff with the gun" by the media and lovingly addressed as "Tonino Bronson" by his colleagues, ${ }^{3}$ Di Maggio stood at the center of a number of controversies related to violence against Roma or other groups. Most of the police who work for the SPE chose to follow him from his previous assignment and profess great appreciation of his leadership. During 
the interview he granted me in August 2015, when asked to describe the security issues linked to campi nomadi, he explained:

The problems are connected to the smoke from pyres [roghi tossici] that are lit day and night. ... They burn the waste that they collect. You go to the mechanic, and he takes ten car batteries and he has to melt them according to the regulations for one hundred euros, for example. But then comes the Roma guy with the van and he proposes to melt ten batteries for thirty euros. ... They collect copper wire, too, but the cables contain plastic, so the Roma burn everything to collect only the copper and they burn the plastic. ... Copper goes to the scrap dealer. ... They take refrigerators from the big supermarkets, ${ }^{4}$ which have pieces of copper that they dismantle and resell, then there's the engine that they send abroad maybe, and then they burn the carcasses to remove the white paint and they resell the metal for fifteen cents per kilogram. ... This is the biggest social alarm in terms of security.

Roghi tossici are the result of a long chain of informal waste management-likely also related to the mafia (Belli et al. 2015)—whose last link are precarious camp inhabitants. Since 2008, when the Roman administration multiplied the evictions of large camps in the city, thus pushing their inhabitants toward the outer periphery in a process of “degypsification” (Bermann and Clough Marinaro 2009), the pyres have intensified as the livelihoods of the Roma have thinned. And yet the Roma, rather than any of the upstream actors, almost exclusively receive the blame for them. Instead of tackling the precarity of camp inhabitants that has confined them to marginal livelihoods, policies have been oriented toward their ever increasing repression. Through such policies, the state became involved in a politics of racketeering (see Tilly 1985), producing the very threats against which it then purported to offer protection. And, importantly, the state focused its policing on those types of nonwage, mostly informal labor that are usually cast outside of the capitalist order.

In order to combat roghi tossici, the SPE deployed two strategies at the time of my research. First, they patrolled some of the camps on a twenty-four-hour basis, stationing teams in a car at the gate that were ready to intervene and make inhabitants extinguish any fire-even the occasional round of outdoor cooking, or the fires lit in barrels on cold evenings to warm up people gathered to chat around them. Second, they took strict control of the scrap metal trade involving Roma, aiming to choke the supply chain. While the upper links of the chain such as supermarkets or companies known to spill construction debris or bulky refuse near camps were mostly 
left untouched, the police focused on either confiscating the vans in which Roma transport the scrap or closing down the businesses of scrap metal traders who buy from Roma. This thinned out Roma livelihoods even more, diverting copious amounts of time and resources toward recovering the confiscated vans and pushing them farther and farther away from the city in search of new scrap dealers who would agree to buy their metal. This made their labor less financially sustainable. During the confiscation of two vans that I witnessed in 2016, the Roma involved accused the police of pushing them to turn to stealing by robbing them of their very means of labor. The work of the police consigned the Roma to an illegality that reinforced the racializing narrative of their innate criminality, which, in turn, justified their repression. Occasionally, one or two of the police would wonder aloud why they keep confiscating vans, since "this is the only useful thing the Gypsies do."

But policing Roma labor is a particular kind of work, one that does work in its own right.

It was November 2015, just days after the terrorist attacks in Paris. Military guards had appeared at the metro and train stations in Rome, and the city was sprinkled with police. I was returning from a patrol with two of the SPE police when they stopped to talk with colleagues from a different precinct who were randomly stopping and searching cars near the Roma Est shopping mall, just a stone throw's away from SPE headquarters. Carlo, who was driving our car, asked the others what they were doing. ${ }^{5}$ After a brief exchange, he stepped on the gas and mumbled: "It's because of the attacks. We didn't get involved in stuff like this. I don't know. It's surely because of these slobs [sarà pe' 'sti zozzoni]," a term I had often heard the commander use in reference to the inhabitants of campi nomadi. While antiterrorism kept other police more respectably busy elsewhere, Carlo felt reduced to merely policing "the Gypsies." Policing the "slobs," as his frustration suggested, did not provide for the symbolic rewards of fighting serious crime in the city, nor for the thrills that he and his colleagues had imagined would come with the job.

Many of the SPE police condemn the poor labor conditions they experience as they patrol squalid camps and deal with people everyone sees as abject. Most of all, they 
complain about the smell and the risk of contracting disease (Racles, and Ivasiuc 2019). Often their reports also decry, in an administrative language sprinkled with picturesque descriptions, the plight of working around campi nomadi:

Carried out night shift at the campo nomadi ... We placed the car ten meters away from the gate and we found ourselves in the middle of a landfill with waste of all kinds where, undisturbed by our presence, tens of rats of remarkable dimensions were running about, crossing the street and climbing the oleanders and the camp fence. Such a situation, which repeats itself every night ... is gravely damaging the professional dignity of the authors, while also being contrary to the regulations in force relative to safety in the workplace (we all know the dire consequences for human health of a bite by such animals). Moreover, the presence of a remarkable quantity of burning waste, placed on the square in front of the camp, causes pollution of the air with harmful substances, also against the most elementary rules for the operators' health. (Police report, June 16, 2015)

Through their repeated complaints, they managed to involve other precincts in regular patrols of the camps, in what was seen by the SPE as a more just division of labor. But the place of the SPE in the social hierarchies of the local police resurfaced as a point of concern several times during my fieldwork. Some police would bitterly admit that their colleagues think of them as "the Gypsy police," with one noting: "The SPE is scorned, we do the dirty work. Our uniforms are less impeccable than if we worked, say, in [the posh neighborhood of] Prati." In contrast to the heroic imaginary of police labor that motivated them to become policemen and women, many complained that the local police are seen as merely those who unjustly dish out fines-an annoyance at best, a repressive force of the state against its own citizens at worst. But as "the Gypsy police," the SPE had sunk even below this level, and their lobbying to involve other precincts in what they called servizio zingari (Gypsy patrolling) attempted to spread more evenly across Rome's police the stigma of working around the campi nomadi.

While this labor of policing generally proved to be ineffective, as the pyres that burn to this day attest, it effectively curtailed the livelihoods of many Roma, channeling fines toward the state and legal fees toward the lawyers of the Roma involved in lawsuits to recover confiscated vans. As in other settings, then, the SPE maintains and reproduces not so much the public order as the capitalist social order that has racialized others doing nonwage forms of labor at the bottom of hierarchies (e.g., Fassin 2011). But while doing the dirty work of policing "the slobs" and their abjectified livelihoods, these workers are themselves pushed to the bottom of police hierarchies. The "dirty 
work" of policing racialized others is perhaps precisely the police labor that best demystifies the idea that the police are around to protect public order and security. Dangerously revealing of the actual role of the police, such work carries the weight of risk and the resonance of taboo.

\section{Notes}

1. The category of tolerated camps comprises those settlements that are not authorized but recognized by the authorities; in principle, they have access to services such as water and electricity provision.

2. Later on, the unit also took over the task of policing unaccompanied migrant minors. On occasion, it has been deployed to carry out evictions of non-Roma, too, and more recently it engaged in combating the illicit trade of counterfeit merchandise that (mostly) immigrants carry out in tourist areas.

3. This was a reference to the U.S. actor Charles Bronson, who was often cast in police officer or vigilante roles.

4. Here, note how the Roma are cast in the active role of those "taking" the used household appliances that retail shops exchange for new purchases, instead of the staff who sell these appliances to the Roma for considerably less effort and money than it would otherwise cost to go through official, environmentally sound channels.

5. This name is a pseudonym.

\section{Author Bio}

Ana Ivasiuc is a social anthropologist whose research interests include the anthropology of security, formal and informal policing, urban studies, and critical Romani studies. Between 2014 and 2017, she carried out research at the Justus Liebig University of Giessen, as part of the Collaborative Research Center Dynamics of Security: Forms of Securitization in Historical Perspective (SFB/TRR 138), funded by the German Research Foundation. Here, she examined the securitization of the Roma in the peripheries of Rome through an ethnography of formal and informal policing, coediting Roma Activism: Reimagining Power and Knowledge (2018) and The Securitization of the Roma in Europe (2019). She currently works at the Center for Conflict Studies in Marburg on informal policing in Germany and the Netherlands through a grant from the Gerda Henkel Foundation's Security, Society, State program. 


\section{Preview Image}

Photo by $\underline{\text { Chris Henry. }}$

\section{References}

Belli, Edoardo, Rossella Granata, Elena Risi and Valentina Vivona. 2015. A ferro e fuoco: Fumi tossici nella "città eterna". Rome: Kogoi.

Bermann, Karen, and Isabella Clough Marinaro. 2011. "Exclusivity and Exclusion: Roma Camps and the 'Degypsification' of the Roman Urbs.” Public 43: 62-75.

Fassin, Didier. 2011. La force de l'ordre: Une anthropologie de la police des quartiers. Paris: Seuil.

Racleș, Andreea, and Ana Ivasiuc. 2019. “Emplacing_Smells: Spatialities and Materialities of 'Gypsiness'." Anthropological Journal of European Cultures 28(1): 1938.

Tilly, Charles. 1985. "War Making and State Making as Organized Crime.” In Bringing the State Back In, edited by Peter Evans, Dietrich Rueschemeyer, and Theda Skocpol, 169-91. New York: Cambridge University Press. 